\title{
Antioxidant and antimicrobial activities of solvent fractions of Vernonia cinerea (L.) Less leaf extract.
}

\author{
Mubo A. Sonibare ${ }^{1}$, Oluwafunmilola T. Aremu ${ }^{1}$, Patricia N. Okorie ${ }^{2}$
}

1. Department of Pharmacognosy, Faculty of Pharmacy, University of Ibadan, Ibadan, Oyo State, Nigeria.

2. Institute for Advanced Medical Research and Training, College of Medicine, University of Ibadan, Ibadan, Nigeria

\begin{abstract}
Background: Vernonia cinerea (L.) Less is used in folk medicine as a remedy for various diseases.

Objectives: The present study reports antioxidant and antimicrobial activities of solvent fractions of Vernonia cinerea.

Methods: The antioxidant properties of solvent fractions of $V$. cinerea were evaluated by determining radicals scavenging activity, total flavonoid and phenolic contents measured with the 2,2-diphenyl-1-picryl hydrazyl (DPPH) test, the aluminum chloride and the Folin-ciocalteau methods, respectively. Antimicrobial activities were tested against human pathogenic microorganisms using agar diffusion method. The minimum inhibitory concentration (MIC) and minimum bactericidal concentration (MBC) of each active extract were determined.

Results: The ethyl acetate fraction having the $\mathrm{IC}_{50}$ value of $6.50 \mu \mathrm{g} / \mathrm{mL}$ demonstrated comparable DPPH radical-scavenging activity with standard antioxidants, gallic acid and quercetin included in the study. All fractions displayed moderate antimicrobial potential against the tested pathogens with the zone of inhibition that ranged from 9.0 to $13.5 \mathrm{~mm}$. The MIC $(1.56 \mathrm{mg} / \mathrm{mL}) \mathrm{and}$ MBC $(3.13 \mathrm{mg} / \mathrm{mL})$ indicated highest susceptibility of Candida albicans in all fractions.

Conclusion: The results of this study showed that the solvent fractions of $V$. cinerea possess antioxidant and antimicrobial activities, hence justifying the folkloric use of the plant for the treatment of various ailments in traditional medicine.

Keywords: Vernonia cinerea, antioxidant activity, antimicrobial activity, total flavonoid content, total phenolic content.

DOI: http://dx.doi.org/10.4314/ahs.v16i2.34

Cite as: Sonibare MA, Aremu OT, Okorie PN. Antioxidant and antimicrobial activities of solvent fractions of Vernonia cinerea (L.) Less leaf extract. Afri Health Sci 2016;16(2): 629-639. bttp:// dx.doi.org/10.4314/ahs.v16i2.34
\end{abstract}

\section{Introduction}

Medicinal plants have played a vital role in the healthcare system of man since the dawn of human civilization. In spite of tremendous development in the field of allopathic medicines during the $20^{\text {th }}$ century, plants still remain one of the major sources of drugs in modern as well as in traditional system of medicine ${ }^{1,2}$. Phenolic compounds are part of the main secondary metabolites, present in plants and these are essential components of human diet. Phenolic compounds are known for their an-
Correspondence author:
Mubo A. Sonibare,
Department of Pharmacognosy,
Faculty of Pharmacy, University of Ibadan,
Ibadan, Nigeria.
E-mail: sonibaredeola@yahoo.com

tioxidant, anti-inflammatory and antimicrobial activities ${ }^{3}$. Flavonoids, which are the most common group of polyphenolic compounds, are ubiquitous in the plant kingdom. They possess antioxidant activity and reduce lipid peroxidation not only by preventing or slowing the onset of cell necrosis but also by improving vascularity ${ }^{4}$.

Vernonia cinerea (L.) Less, belonging to the family Asteraceae is an annual plant widely distributed in India, Bangladesh, Sri Lanka and Malay island ${ }^{5}$. Vernonia cinerea is one of the species of Vernonia found in Nigeria and it is known as a weed". It is commonly known as 'little ironweed' in English, "bojure" in Yoruba and "oriwo" in $\mathrm{Edo}^{7,8}$. The plant is extensively used in indigenous medicine in stomach aches and for cold, asthma and bronchitis ${ }^{9}$. The Ayurveda Pharmacopoeia of India recommends the plant for the treatment of intermittent fever, filariasis, blisters, boils and vaginal discharges. The root of the plant is used traditionally for the treatment of all types of 
eruptive boils and the juice is used for faster healing of accidental wounds, filariasis and toxic viral fevers.

The seeds are used in dysuria and to treat colic in the form of decoction ${ }^{8}$. Young leaves of the plant are used for the treatment of tonsillitis ${ }^{10}$. The leaf juice extract is used to treat skin diseases and the leaf extract for treating dysentery in children ${ }^{11}$. Besides these, the plant is used in smoking cessation, cough, fever, malaria, urinary calculi, arthritis and leprosy ${ }^{12,13,14,15}$. The plant possesses antimicrobial $^{16}$, antibacterial ${ }^{17}$, antioxidant ${ }^{18}$, antihelmentic, antiinflammatory, analgesic, antipyretic ${ }^{17,19,20}$, antiflautulent, antispasmodic ${ }^{8}$ and antidiuretic properties ${ }^{21}$. Some of the phytochemical compounds that have been reported on the plant include: sterols, flavonoids, sesquiterpene lactones $^{22}$ and a terpenoid, 'leupeol acetate' which show antihyperglycaemic and antiulcer properties ${ }^{23}$. Furthermore, Vernonia cinerea also possesses insect-antifeedant property $^{24}$.

The present study was carried out to determine the total phenolic and flavonoid content and to evaluate the antioxidant and antimicrobial activities of the partitioned fractions of Vernonia cinerea.

\section{Materials and methods}

\section{Chemicals and reagents}

All solvents and acid used in this study were purchased analytical grade. The quercetin and gallic acid standards used for total phenolic and flavonoid content were procured from Sigma-Aldrich, Germany. The other chemical reagents were from $\mathrm{BDH}, \mathrm{UK}$. The absorbances were measured using Spcetrumlab 752S UV-VIS Spectrophotometer.

\section{Plant collection and identification}

The whole plant of Vernonia cinerea was collected in July, 2013 from the botanical garden, University of Ibadan, Ibadan, Oyo State, Nigeria. Plant identification was done by Mr. O. A. Osiyemi at the Forest Herbarium, Ibadan (FHI), Nigeria, where a voucher specimen FHI 109827 was deposited. The fresh and healthy plants were separated from the sterile ones and packed in a polythene bag. Samples were transported to the laboratory and kept at room temperature until processing.

\section{Preparation of extracts}

The whole plant samples of Vernonia cinerea were dried under shade at room temperature for seven days and ground into powder using an electric grinding machine. The sample (500 g) was extracted continuously for seven days at room temperature with seven liters of methanol with intermittent stirring. The extract was filtered using Whatman filter paper no. 1 and the residue was further extracted with five liters of methanol. Filtrates were combined and evaporated using rotary evaporator (Heidolph, Laborota 4000). The crude extract (21.89 g) was partitioned with $n$-hexane (3x), chloroform (3x) and ethyl acetate $(3 \mathrm{x})$. Each combined solvent fraction was concentrated at $40^{\circ} \mathrm{C}$ and weighed to give $n$-hexane $(\mathrm{VNH}, 3.6$ $\mathrm{g})$, chloroform (VCH, $1.17 \mathrm{~g}$ ), ethyl acetate (VEF, $1.42 \mathrm{~g}$ ) fractions, respectively. The residual aqueous fraction was $7.29 \mathrm{~g}$ in weight. The fractions were stored at $4^{\circ} \mathrm{C}$ until needed for analysis.

\section{Determination of total phenolic and flavonoid con- tent}

The total phenolic content (expressed as TPC) was determined by the Folin-ciocalteau method reported in literature with slight modifications ${ }^{25}$. The standard calibration curve was plotted using gallic acid at the concentrations of $0.02-0.1 \mathrm{mg} / \mathrm{mL}$. The assay was done by mixing 0.75 $\mathrm{mL}$ of 10 -fold diluted Folin-Ciocalteau reagent and 100 $\mu \mathrm{L}$ of each solvent extract in a test tube. The mixture was allowed to stand at room temperature for $5 \mathrm{~min}$, after which $0.75 \mathrm{~mL}$ of $6 \%(\mathrm{w} / \mathrm{v})$ sodium carbonate $\left(\mathrm{Na}_{2} \mathrm{CO} 3\right)$ solution was added. The mixture was homogenized and allowed to stand at room temperature for $90 \mathrm{~min}$. Mixture turned blue on adding $6 \%(\mathrm{w} / \mathrm{v}) \mathrm{Na}_{2} \mathrm{CO} 3$ solution indicating the presence of phenolics. Optical density of the sample was measured at $725 \mathrm{~nm}$ in triplicates using a Spcetrumlab 752S UV-VIS Spectrophotometer and the standard curve was drawn. The total phenolic contents were expressed as $\mathrm{mg}$ gallic acid equivalent (GAE) / g dry weight.

Colorimetric aluminium chloride method was used for total flavonoid content determination ${ }^{26,27}$. Briefly, 0.5 $\mathrm{mL}$ solution of each extracts in methanol was separately mixed with $1.5 \mathrm{~mL}$ of methanol, $0.1 \mathrm{~mL}$ of $10 \%$ aluminium chloride, $0.1 \mathrm{~mL}$ of $1 \mathrm{M}$ potassium acetate and $2.8 \mathrm{~mL}$ of distilled water and left at room temperature 
for $30 \mathrm{~min}$. The absorbance of the reaction mixture was measured at $415 \mathrm{~nm}$ using Spcetrumlab 752S UV-VIS Spectrophotometer. The calibration curve was prepared using quercetin solutions at 6.25 to $100 \mu \mathrm{g} / \mathrm{mL}$ in methanol. Determination was done in triplicates. Total flavonoid contents were expressed as milligrams of quercetin equivalent (QE) / g dry weight.

\section{Determination of antioxidant activity by DPPH free radical scavenging assay}

The 2, 2-diphenyl-1-picrylhydrazyl free radical-scavenging activity was determined by standard methods with slight modification $^{28,29}$. Various concentrations $(100,80,60,40$, 20,10 , and $5 \mu \mathrm{g} / \mathrm{mL}$ ) of the solvent fractions of $V$. cinerea were prepared in methanol. The DPPH solution was freshly prepared for the assay. Each extract solution (2 $\mathrm{mL}$ ) was mixed with $1 \mathrm{~mL}$ of methanol solution containing DPPH radicals $(0.2 \mathrm{mM})$. The reaction mixtures were prepared under dim light, shaken vigorously and maintained for $30 \mathrm{~min}$ in the dark after which the absorbance was measured at $517 \mathrm{~nm}$ using a UV-VIS Spectrophotometer. The absorbance of the control was obtained by replacing the sample with methanol. Quercetin and gallic acid were used as standards. The scavenging activity was calculated using the formula:

Scavenging activity $(\%)=($ A517 of control - A517 of sample) / A517 of control x100.

$\mathrm{IC}_{50}$ values (the concentration of sample, which is required to scavenge $50 \%$ of DPPH radicals) were determined.

\section{Antimicrobial Susceptibility Test}

The organisms used for the antimicrobial tests were obtained from the Medical Microbiology Department, College of Medicine, University College Hospital (U.C.H.), Ibadan, Oyo State, Nigeria. Pure cultures of bacteria: Staphylococcus aureus (UCH 7580), Escherichia coli (UCH 6504), Klebsiella pneumonia (UCH 7545), Pseudomonas aeruginosa (UCH 7450), Bacillus subtillis (UCH 8536), and Proteus vulgaris (UCH 7206), were maintained on Mueller-Hinton agar slants at $4^{\circ} \mathrm{C}$, while the fungi: Candida albicans $(\mathrm{UCH}$ 8128) and Aspergillus flavus (UCH 9892) were maintained on Sabourauds' Dextrose Agar at $4^{\circ} \mathrm{C}$.

The antibacterial activity of the solvent fractions of $V$. cinerea was determined by the agar diffusion method using the well technique proposed by the Clinical and Laboratory Standards Institute ${ }^{30}$. Bacterial and fungal cells suspension with equilibrated concentration of a $0.5 \mathrm{McF}$ arland standard in sterile saline were used to achieve concentration of $107 \mathrm{CFU} / \mathrm{mL}$ and 106 spores/mL, respectively. Briefly, all samples were dissolved in dimethyl-sulfoxide (DMSO $10 \%, \mathrm{v} / \mathrm{v}$ ) at $10 \mathrm{mg} / \mathrm{mL}$. Inoculum of the bacterial and fungal strains was spread using sterile swabs into petri dishes with $15 \mathrm{~mL}$ of Mueller-Hinton Agar (MHA) and Sabouraud Dextrose Agar (SDA), respectively. Sterile cork borer of $6 \mathrm{~mm}$ diameter was used to make five ditches (wells) on each inoculated plate and filled with $100 \mu \mathrm{L}$ of the extracts and only DMSO as negative control. The plates were incubated at $37^{\circ} \mathrm{C}$ and $25^{\circ} \mathrm{C}$ for 24 $\mathrm{h}$ and $48 \mathrm{~h}$, respectively. After incubation time, zone of inhibition was measured. The experiment was performed in triplicates.

Antibiotic susceptibility test was carried out on the test bacteria as positive control. A multi-sensitivity disc bearing different antibiotics was used against each of the test bacteria. Each of these was inoculated on Mueller Hinton agar plates and incubated at $37^{\circ} \mathrm{C}$ for $24 \mathrm{~h}$. The antibiotics were- GBMTS-NEG (Lot: NH05/P) (Abtek Biologicals Ltd. Liverpool L9 7AR, UK) consisting of: ceftazidine $(30 \mu \mathrm{g})$, cefuroxime $(30 \mu \mathrm{g})$, nitrofurantoin $(300 \mu \mathrm{g})$, gentamicin $(10 \mu \mathrm{g})$, cefixime $(5 \mu \mathrm{g})$, ofloxacin $(5 \mu \mathrm{g})$, augmentin $(30 \mu \mathrm{g})$, ciprofloxacin $(30 \mu \mathrm{g})$; and DTPOS (Lot: JB04/P) consisting of ceftazidine $(30 \mu \mathrm{g})$, cefuroxime $(30 \mu \mathrm{g})$, cloxacillin $(5 \mu \mathrm{g})$, erythromycin $(5 \mu \mathrm{g})$, gentamicin $(10 \mu \mathrm{g})$, ceftriaxone $(30 \mu \mathrm{g})$, ofloxacin $(5 \mu \mathrm{g})$ and augmentin $(30 \mu \mathrm{g})$.

\section{Determination of Minimum Inhibitory Concentra- tion (MIC) and Minimum Bactericidal Concentra- tion (MBC)}

Minimum inhibitory concentration is defined as the lowest concentration of the antimicrobial agent that will inhibit the visible growth of a microorganism after overnight incubation ${ }^{31,32,33}$. The MIC and MBC of $V$. cinerea solvent fractions were determined by macrodilution agar and broth methods $\mathrm{s}^{31,32}$. In the macro dilution agar method, a two-fold serial dilution of $V$. cinerea fractions was prepared in $10 \%(\mathrm{v} / \mathrm{v})$ DMSO to achieve a decreasing concentration range of $100-0.78 \mathrm{mg} / \mathrm{mL}$. Sterile cork 
borer of $6 \mathrm{~mm}$ diameter was used to bore well in the pre-solidified MHA plates in triplicates that had the cell suspension seeded with the standardized inoculum that has been adjusted to $0.5 \mathrm{McF}$ arland standard. The control well was seeded with $100 \mu \mathrm{L}$ DMSO only without plant extract. All the test plates were incubated at $37^{\circ} \mathrm{C}$ and observed for growth for $24 \mathrm{~h}$. The lowest concentration of any fraction showing a clear zone of inhibition was considered as the MIC.

In the macrodilution broth method, a two-fold serial dilution of the fractions was prepared in sterile $\mathrm{BHI}$ broth to achieve a decreasing concentration of $100-0.78 \mathrm{mg} /$ $\mathrm{mL}$. Each was seeded with $100 \mu \mathrm{L}$ of the standardized inoculum. The inoculated culture tubes were incubated at $37^{\circ} \mathrm{C}$ for $18-24 \mathrm{~h}$. A set of tubes containing only seeded broth (i.e. without plant extract) was kept as control. The lowest concentration that did not permit any visible growth when compared with control was considered as the MIC.

The MBC is the lowest concentration of antimicrobial agent that will prevent the growth of an organism after subculture on to antibiotic - free media. To determine MBC, a $100 \mu \mathrm{L}$ aliquot from the tube showing MIC was placed on MHA antibiotic - free plate and was spread over the plate. After incubation at $37^{\circ} \mathrm{C}$ for $24 \mathrm{~h}$, the plates were examined for growth of bacteria to determine the concentration of extract at which $99.9 \%$ killing of bacterial isolates was achieved.

\section{Statistical analysis}

All experimental results were expressed as mean \pm standard error of the mean of obtained measurements. The results with $\mathrm{P}<0.05$ were regarded to be statistically significant. The $\mathrm{IC}_{50}$ values for the DPPH antioxidant activity were calculated by linear regression analysis.

\section{Results}

\section{Total phenolics and flavonoids contents}

The total phenolic content in $\mathrm{mg}$ gallic acid equivalent $/ \mathrm{g}$ of extract by reference to standard curve $(y=14.289 x+$ $0.1042, \mathrm{r} 2=0.9831)$ and flavonoid reported as mg quercetin equivalent/g of extract, by reference to standard curve $(y=0.0157 x+0.0451, r 2=0.9973)$ for the fractions are summarized in Table 1 . The ethyl acetate fraction gave the highest phenolic $(8.17 \pm 1.54 \mathrm{mg} \mathrm{GAE} / \mathrm{g})$ and flavonoid contents $(5.86 \pm 0.24 \mathrm{mg}$ GAE/g) followed by the chloroform fraction. The lowest phenolic content of $2.78 \pm 0.19 \mathrm{mg}$ GAE/g was obtained from the hexane fraction.

\section{Table1. Total Phenolics Content (TPC) and Total Flavonoids Content (TFC) in methanolic extract and fractions of Vernonia cinerea $(\mathrm{L}$.$) Less$}

\begin{tabular}{lcc}
\hline Extract & Total Phenols $(\mathrm{mg} \mathrm{GAE} / \mathrm{g})$ & Flavonoids $(\mathrm{mg}$ quercetin/g) \\
\hline VNH & $2.78 \pm 0.19$ & $4.17 \pm 0.54$ \\
VCH & $4.55 \pm 1.30$ & $4.48 \pm 1.47$ \\
VEA & $8.17 \pm 1.54$ & $5.86 \pm 0.24$ \\
Data are represented as & Mean \pm S.E.M (n=3). VNH- $V$. cinerea $n$-hexane fraction, VCH- $V$. \\
cinerea chloroform fraction, VEA- $V$. cinerea ethyl acetate fraction.
\end{tabular}

\section{DPPH free radical scavenging activity}

The results of antioxidant activity of the fractions determined by the DPPH free radical scavenging assay are shown in Table 2. The dose dependent activity was in the order: ethyl acetate $>$ hexane $>$ chloroform, fractions.
The ethyl acetate fraction exhibited $63.3 \%$ DPPH radical scavenging activity at $100 \mu \mathrm{g} / \mathrm{mL}$. The $50 \%$ inhibitory concentrations $\left(\mathrm{IC}_{50}\right)$ indicating the radical scavenging activity of the fractions revealed the ethyl acetate fraction with $\mathrm{IC}_{50}$ of $6.50 \mu \mathrm{g} / \mathrm{mL}$ as exhibiting the highest radical 
scavenging activity followed by the hexane fraction with $\mathrm{IC}_{50}$ of $8.00 \mu \mathrm{g} / \mathrm{mL}$, while the lowest activity was found in the chloroform fraction with $\mathrm{IC}_{50}$ value of $8.63 \mu \mathrm{g} /$ mL. Gallic acid and Quercetin had the $\mathrm{IC}_{50}$ values of 0.62 and $0.53 \mu \mathrm{g} / \mathrm{mL}$, respectively.

\section{Table 2. DPPH radical scavenging activity of Vernonia cinerea solvent fractions}

\begin{tabular}{llllll}
\hline $\begin{array}{l}\text { Conc. } \\
\mu \mathrm{g} / \mathrm{mL}\end{array}$ & Gallic acid & Quercetin & VNH & VCH & VEA \\
\hline 100 & $92.18 \pm 0.00$ & $91.32 \pm 0.00$ & $44.5 \pm 1.30$ & $41.56 \pm 1.73$ & $63.33 \pm 3.64$ \\
80 & $92.17 \pm 0.14$ & $91.06 \pm 0.13$ & $43.67 \pm 2.66$ & $40.23 \pm 3.44$ & $61.24 \pm 4.26$ \\
60 & $92.10 \pm 0.31$ & $91.24 \pm 0.07$ & $40.75 \pm 1.29$ & $39.51 \pm 1.06$ & $60.51 \pm 2.76$ \\
40 & $92.09 \pm 0.14$ & $91.09 \pm 0.12$ & $36.62 \pm 1.38$ & $37.32 \pm 1.15$ & $19.25 \pm 3.09$ \\
20 & $92.09 \pm 0.14$ & $90.97 \pm 0.13$ & $35.80 \pm 0.92$ & $35.06 \pm 1.01$ & $10.36 \pm 2.10$ \\
10 & $92.05 \pm 0.12$ & $90.81 \pm 0.05$ & $31.31 \pm 1.92$ & $34.89 \pm 2.00$ & $12.31 \pm 1.04$ \\
5 & $91.97 \pm 0.14$ & $90.76 \pm 0.05$ & $29.06 \pm 1.72$ & $29.63 \pm 1.45$ & $10.14 \pm 1.75$ \\
\hline VNH $=V$. cinerea $n$-hexane & fraction, VCH $=V$. cinerea & chloroform fraction, VEA $=V$. \\
cinerea ethyl acetate fraction & & & &
\end{tabular}

Antimicrobial Activity

The antimicrobial activities of the fractions of $V$. cinerea fungi are shown in Figure 1.

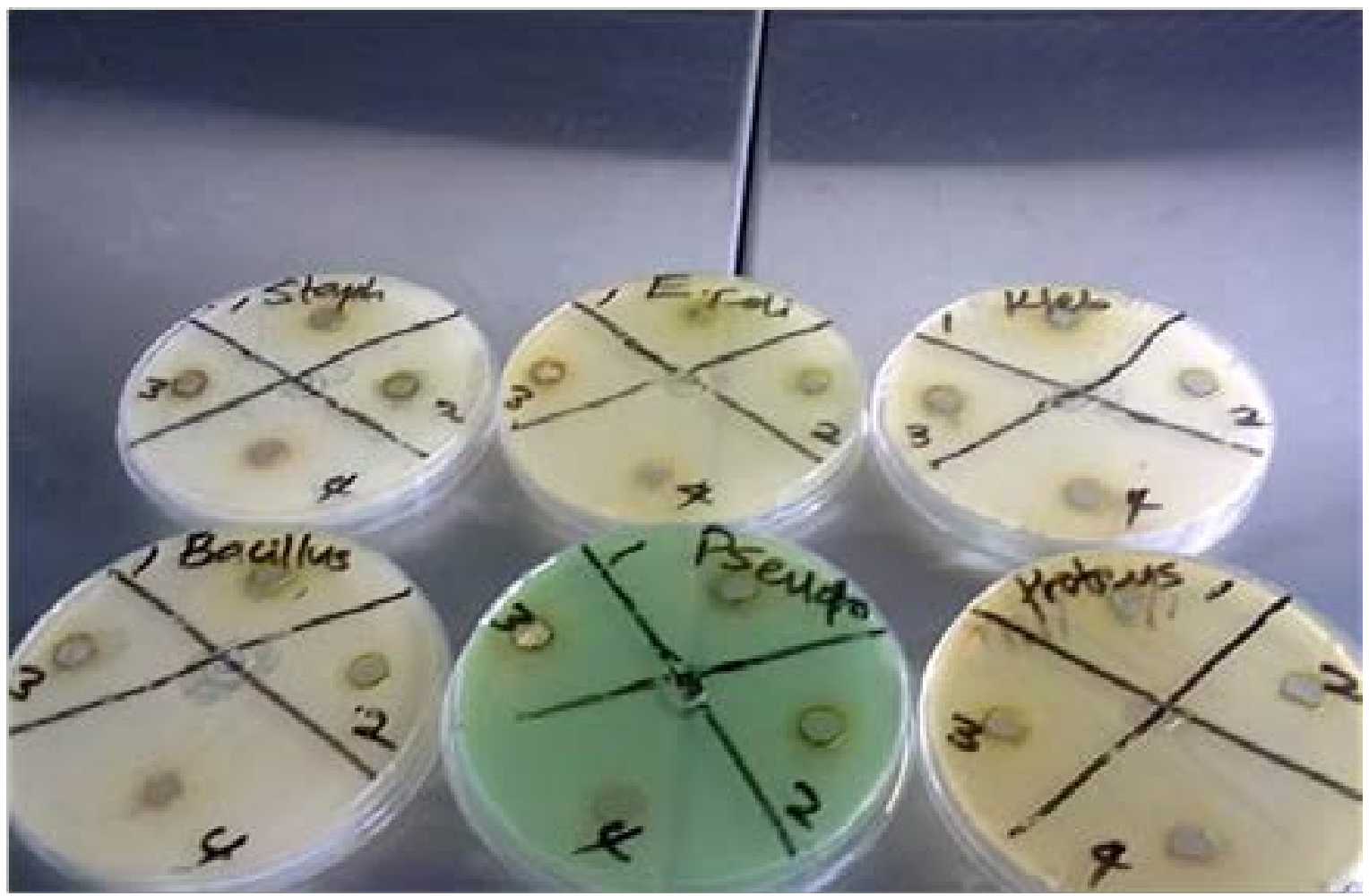

Figure 1. Plates showing zone of inhibition of Vernonia cinerea fractions. 1- VCME

(V. cinerea crude methanol), 2- VNH (V. cinerea $n$-hexane fraction),

3- VCH (V. cinerea chloroform fraction), 4- VEA (V. cinerea ethyl acetate fraction) 
In the present study, six bacteria and two fungi were examined. The fractions exhibited differential effects on the test organisms. The maximum antimicrobial activity was observed with the ethyl acetate fraction followed by chlo- roform fraction with the zone of inhibition of 13.5 and $12.8 \mathrm{~mm}$ against Escherichia coli, Pseudomonas aeruginosa and Bacillus subtilis, respectively. Aspergillus flavus was resistant to all the fractions (Table 3 ).

\section{Table 3. Antimicrobial activities of Vernonia cinerea solvent fractions against tested microorganisms.}

\begin{tabular}{|c|c|c|c|c|c|c|c|c|}
\hline \multirow{3}{*}{ Organisms } & \multicolumn{8}{|c|}{ Zone of inhibition (mm) } \\
\hline & \multicolumn{2}{|c|}{ Gram positive bacteria } & \multicolumn{3}{|c|}{ Gram negative bacteria } & \multicolumn{3}{|c|}{ Fungi } \\
\hline & S. aureus & B. subtilis & E. coli & $\begin{array}{l}K . \\
\text { pneumoniae }\end{array}$ & $\begin{array}{l}P . \\
\text { aeruginosa }\end{array}$ & $\begin{array}{l}P . \\
\text { vulgaris }\end{array}$ & $\begin{array}{l}\text { C. } \\
\text { albicans }\end{array}$ & $\begin{array}{l}\text { A. } \\
\text { flavus }\end{array}$ \\
\hline $\mathrm{VNH}$ & $10 \pm 0.76$ & - & $11.0 \pm 0.57$ & $11.8 \pm 1.83$ & $9.6 \pm 0.44$ & $10.5 \pm 0.50$ & $10.2 \pm 0.44$ & - \\
\hline $\mathrm{VCH}$ & $10 \pm 0.28$ & $12.6 \pm 1.36$ & $12.0 \pm 0.50$ & $11.7 \pm 0.72$ & $12.8 \pm 072$ & $12.0 \pm 0.28$ & $10.2 \pm 0.67$ & - \\
\hline VEA & $10.2 \pm 0.44$ & $13.0 \pm 0.76$ & $13.5 \pm 2.02$ & $12.8 \pm 0.44$ & $12.7 \pm 0.72$ & $12.8 \pm 1.09$ & $10.2 \pm 0.16$ & - \\
\hline DMSO & - & - & - & - & - & - & - & - \\
\hline
\end{tabular}

VCME- Vernonia cinerea crude methanolic extract, VNH- $V$. cinerea n-Hexane fraction, VCH- $V$. cinerea chloroform fraction, VEA- $V$. cinerea Ethyl acetate fraction.

The solvent used for control (DMSO) did not show any ria and the antifungal susceptibility pattern to fluconazole activity. The antibiotic resistant pattern of the test bacte- $(10 \mathrm{mg} / \mathrm{mL})$ are presented in Tables 4 and 5 , respectively. 
Table 4. Antibiotic Resistant Pattern of the Test Bacteria

\begin{tabular}{lll}
\hline Bacteria & Antibiotics Susceptibility & Antibiotics Resistance \\
\hline Gram positive & & \\
S. & OFL, GEN, ERY & AUG, CAZ, CRX, CTR, \\
aureus & OFL, GEN & CXC \\
B. subtilis & & AUG, CAZ, CRX, CTR, \\
& & CXC, ERY \\
Gram negative & & \\
E. coli & GEN,OFL, CPR,NIT & CAZ, AUG, CIP \\
K. pneumoniae & CAZ, AUG & CRX, GEN, OFL, CPR \\
$P$. aeruginosa & GEN,OFL, CPR & CAZ, CRX, AUG. \\
$P$. vulgaris & CAZ, AUG & CRX, GEN,OFL,CPR \\
& & \\
\hline
\end{tabular}

Keys: OFL- Ofloxacin, GEN- Gentamicin, ERY- Erythromycin, CPR- Ciprofloxacin, NIT- Nitrofurantoin, CAZCeftazidine, CRX- Cefuroxime, AUG- Augmentin, CTR- Ceftriaxone, CXC-Cloxacillin.

Table 5. Antifungal Susceptibility pattern to Fluconazole $(10 \mathrm{mg} / \mathrm{mL})$

\begin{tabular}{lc}
\hline Fungi & Susceptibility pattern \\
\hline Candida albican & Susceptible \\
Aspergillus flavus & Resistant \\
\hline
\end{tabular}

To compare the sensitivity of the bacterial strains to the fractions, each active fraction was used to determine the MIC and MBC. The MIC and MBC indicated highest susceptibility of Candida albicans in all extracts with MIC value of $1.56 \mathrm{mg} / \mathrm{mL}$ and $\mathrm{MBC}$ value of $3.13 \mathrm{mg} / \mathrm{mL}$ (Table 6). 
Table 6. Minimum inhibitory and bactericidal concentration $(\mathrm{mg} / \mathrm{mL})$ of methanolic extract and solvent fractions of Vernonia cinerea $(\mathrm{L}$.$) Less.$

\begin{tabular}{|c|c|c|c|c|c|c|}
\hline \multirow[t]{2}{*}{ Organisms } & \multicolumn{2}{|l|}{ VNH } & \multicolumn{2}{|l|}{$\mathrm{VCH}$} & \multicolumn{2}{|l|}{ VEA } \\
\hline & MIC & $\mathrm{MBC}$ & MIC & MBC & MIC & $\mathrm{MBC}$ \\
\hline \multicolumn{7}{|l|}{ Gram positive } \\
\hline S. aureus & 1.56 & 3.13 & 3.13 & 6.25 & 6.25 & 12.5 \\
\hline B.subtilis & ND & ND & 6.25 & 12.5 & 3.13 & 6.25 \\
\hline $\begin{array}{l}\text { Gram } \\
\text { negative } \\
\text { E.coli }\end{array}$ & 6.25 & 12.5 & 3.13 & 6.25 & 3.13 & 6.25 \\
\hline K. pneumoniae & 3.13 & 6.25 & 3.13 & 6.25 & 1.56 & 3.13 \\
\hline$P$. aeruginosa & 3.13 & 6.25 & 3.13 & 6.25 & 6.25 & 12.5 \\
\hline $\begin{array}{l}P . \text { vulgaris } \\
\text { Fungi }\end{array}$ & 3.13 & 6.25 & 1.56 & 3.13 & 1.56 & 3.13 \\
\hline C.albican & 1.56 & 3.13 & 1.56 & 3.13 & 1.56 & 3.13 \\
\hline A.flavus & ND & ND & ND & ND & ND & ND \\
\hline
\end{tabular}

\section{Discussion}

This study provides information on the total phenolic and flavonoid contents of $V$. cinerea in relation to the antioxidant and antimicrobial activities demonstrated by solvent fractions of $V$. cinerea, which is an important medicinal plant. Antioxidants are important in preventing human diseases. Sources of antioxidants are generally plant phenolics that can be found in all parts of plant. Plant-derived phenolics such as flavonoids are of great importance because they exhibit antioxidant properties due to their high redox potential ${ }^{34}$. Phenolics exhibit a considerable free radical scavenging (antioxidant) activity, which is determined by their reactivity as hydrogen-orelectron donating agents. The DPPH free radical scavenging test in this study was conducted to evaluate the solvent fractions of $V$. cinerea for antioxidant activity. The total phenolic and flavonoid contents were also determined. The results indicate that the solvent fractions of the whole plant extract of $V$. cinerea exhibited a potential free radical scavenging activity. In line with the reports from other studies ${ }^{35}$, the ethyl acetate, a medium polar solvent was observed to be more effective in the extraction of antioxidant substances from $V$. cinerea plant. Previous studies have reported the use of methanol, ethanol, acetone, propanol, ethylacetate and dimethylformamide for the extraction of phenols from fresh produce ${ }^{36}$. The recovery of polyphenols from plant materials is influenced by their solubility in the extraction solvent, the type of solvent, the degree of polymerization of phenols, the interaction of phenols with other plant constituents and the formation of insoluble complexes ${ }^{37}$. The differences in the polarity of antioxidants have been reported to be capable of explaining differences in extraction yield and antioxidant activities, which in effect play a key role in increasing phenolic solubility that, may affect the antioxidant activity $^{38}$. The present study demonstrated direct relationship between the TPC and TFC and antioxidant activity. Most studies have reported correlation between the total phenolics and antioxidant activity ${ }^{39}$, our results on the antioxidant activity of $V$. cinerea also indicate such correlation. Although there are some literature reports on findings that suggest little or no correlation between phenolic content and antioxidant activity $2,40,41,42,43$, the present study shows good correlation between both flavonoid and phenolic contents and antioxidant activity.

The agar diffusion methods used in this study to test antimicrobial activity of the plant extracts have been widely 
reported in literature ${ }^{44,45}$. All test organisms expressed various resistant pattern when tested against known commercially available antibiotics. The fractions showed antimicrobial activity against clinical isolates of microorganisms comprising of six bacteria and a Candiada species. The antibacterial and antifungal activities of the whole plant of $V$. cinerea in the study showed that the plant is a broad spectrum antimicrobial agent since it inhibited the growth of disease-causing Gram-positive bacteria ( $S$. aureus, B. subtilis) and Gram-negative bacteria (E. coli, K. pneumonia, $P$. aeruginosa, $P$. vulgaris) as well as $C$. albicans. However, $A$. niger was resistant to the extracts. Other workers had reported a similar finding, reporting that fungi are more resistant to plant extracts than bacteria ${ }^{46},{ }^{47,48}$. The resistance exhibited by $A$. niger to the tested fractions could be due to the presence of more complex cell wall in fungi. This could also be because of the ability of fungi to produce extracellular enzymes that help in degrading and metabolizing substrates such that the extract acts as a source of food to the fungi rather than inhibiting their growth $^{49}$. The results confirmed that the non-polar and medium polar solvent fractions of $V$. cinerea are potential sources of antimicrobial agents. However, in line with the results on the antioxidant activity, the ethyl acetate fraction showed better antimicrobial activity. The results of our study showed that there was a disparity between the fractions and standard antibiotics as the former inhibited the growth of organisms which some of the standard antibiotics failed to inhibit. The disparity may be due to the mixtures of bioactive compounds present in the fractions of $V$. cinerea compared to the pure compound contained in the standard antibiotics used in the study ${ }^{50}$. There were substantial differences between the MIC and MBC values of various fractions. These results demonstrated that the $\mathrm{VNH}, \mathrm{VCH}$ and VEA fractions obtained from the whole plant possess a high antimicrobial activity. The most susceptible bacteria were B. subtilis and E. coli.

\section{Conclusion}

The present study shows that the solvent fractions of Vernonia cinerea possess antimicrobial activities against most of the human pathogenic bacteria tested. The most susceptible organisms were Bacillus subtilis, Escherichia coli and Pseudomonas aeruginosa. The fractions also demonstrated antioxidant activity which correlated with the amount of total phenolic and total flavonoid contents that were obtained in the plant. The ethyl acetate fraction demonstrated the highest activity, thus could be explored as a candidate for future search for antimicrobial agents for the cure and management of different ailments based on further studies.

\section{Conflict of interest}

The authors declare that we have no conflict of interest

\section{Acknowledgments}

The study received partial financial support from the University of Ibadan Senate research grant SRG/FP/2010/4 A.

\section{References}

1. Khalil MY, Moustafa AA, Naguib NY: Growth, phenolic compounds and antioxidant activity of some medicinal plants grown under organic farming condition. World J Agric Sci 2007; 3(4): 451-457.

2. Sengul M, Yildiz H, Gungor N, Cetin B, Eser Z, Ercisli S: Total phenolics content, antioxidant and antimicrobial activities of some medicinal plants. Pak J Pharm Sci 2009; 22(1): 102-106.

3. Klančnik A, Piskernik S, Jeršek B, Možina SS: Evaluation of diffusion and dilution methods to determine the antibacterial activity of plant extracts. J Microbiol Methods 2010; 81: 121-126.

4. Sakunpak A, Panichayupakaranant P: Antibacterial activity of Thai edible plants against gastrointestinal pathogenic bacteria and isolation of a new broad spectrum antibacterial polyisoprenylated benzophenone, chamuangone. Food Chem 2012; 130: 826-831.

5. Harbone JB: Phytochemical Methods: A guide to modern technique of plant analysis. London: Chapman and Hall; 1998.

6. Oladele FA. Leaf Epidermal Features in Vernonia amygdalina and Vernonia cinerea. Nig J Bot 1990; 3: 71-77.

7. Pattanayak S, Datta MK: Some ornamental plants with tiny flowers for gardens. Nat Prod Rad 2008; 7(4): 342343.

8. Varghese KJ, Anila J, Nagalekshmi R, Resiya S, Sonu J. Dasapushpam: The traditional uses and the therapeutic potential of ten sacred plants of Kerala state in India. Int J Pharm Sci Res 2010; 1(10): 50-59.

9. Kirtikar KR, Basu BD: Indian Medicinal Plants. New Delhi: Sri Satguru Publication; 2000.

10. Hamill FA, Apio S, Mubiru NK, Bukenya-Ziraba R, Mosango M, Maganyi $\mathrm{O}$ et al.: Traditional herbal drugs of Southern Uganda, II: literature analysis and antimicrobial assays. J Ethnopharmacol 2003; 84: 57-78. 
11. Maruthupandian A, Mohan VR: Observations of ethnomedicinal plants from Sirumalai hills in Western Ghats of Tamilnadu, India. J Herbal MedToxicol 2010: 4(2): 89 $-92$.

12. Lhieochaiphant SA: Phytochemical study of Vernonia cinerea Less. 1985; M.Sc. Thesis, Chiangmai University.

13. Bunyapraphatsara N: Medicinal plants indigenous to Thailand. Bangkok: Mahidol University; 2005.

14. Lin KW: Ethnobotanical study of medicinal plants used by the Jah Hut people in Malaysia. Indian J Med Sci 2005; 59: 156-161.

15. Vijayan MN, Barreto I, Dessai S, Dhuri S, D'Silva $\mathrm{R}$, Rodrigues A. Antimicrobial activity of ten common herbs, commonly known as 'Dashapushpam' from Kerala, India. Afr J Microbiol Res 2010; 4(22): 2357-2362.

16. Yoga LL, Darah I, Sasidharan S, Jain K: Antimicrobial activity of Emilia sonchifolia DC, Tridax procumbens L. and Vernonia cinerea L. of Asteraceae Family: Potential as Food Preservatives. Malaysian J Nutr 2009; 15 (2): 223-231.

17. Gupta M, Mazumdar UK, Manikandan L, Haldar PK, Bhattarchya S:Antibacterial activity of Vernonia cinerea. Fitoterapia 2003; 74: 148-150.

18. Misra TN, Singh RS, Upadhyay J, Srivastava R: Chemical constituents of Vernonia cinerea. Part I. Isolation and spectral studies of triterpenes. J NatProd 1984; 47: 368372.

19. Iwalewa EO, Iwalewa OJ, Adeboye JO: Analgesic, antipyretic, anti-inflammatory effects of methanol, chloroform and ether extracts of Vernonia cinerea Less. Leaf. J Ethnopharmacol 2003; 86: 229-234.

20. Mazumder UK, Gupta M, Manikandan L, Bhattacharya S, Haldar PK, Roy S: Evaluation of anti-inflammatory activity of Vernonia cinerea extract in rats. Phytomedicine 2003; 10: 185-188.

21. Herrera CL, Sison FM, Paras YCL, Dayap A, Banal IU: Diuretic principles from Vernonia cinerea. Phil J Sci 1998; 127: 93-102.

22. Chopra RN, Chopra IC, Verma BS: Supplement to glossary of Indian Medicinal Plants. New Delhi: Council of Scientific and Industrial Research; 1992.

23. Harbone JB, Baxter HA: A dictionary of plant toxins. England: John Wiley and Sons Limited; 1996.

24. Tandon, M, Shukla YN, Prapathi AK, Singh SC: Insect antifeedant principles from Vernonia cinerea. Phytother Res 1999; 12: 195-199.

25. Velioglu YS, Mazza G, Gao L, Oomah BD: Antioxi- dant capacity and total phenolics in selected fruits, vegetables and grain products. J Agric Food Chem 1998; 46: 4113-4117 PubMed.

26. Nabavi SM, Ebrahimzadeh MA, Nabavi SF, Hamidinia A, Bekhradnia AR: Determination of antioxidant activity, phenol and flavonoids content of Parrotia persica Mey. Pharmacol Online 2008; 2: 560-567.

27. Ebrahimzadeh MA, Bahramian F: Antioxidant activity of Crataegus pentagina subsp. elbursis fruit extracts used in traditional medicine in Iran. Pak J Biol Sci 2009; 12 (5): 413-419.

28. Shimada K, Fujikawa K, Yahara K, Nakamura T: Antioxidative properties of xanthan on the autoxidation of soybean oil in cyclodextrin emulsion. I Agric Food Chem 1992; 40: 945-948.

29. Yang B, Wang JS, Zhao MM, Liu Y, Wang W, Jiang YM: Identification of polysaccharides from pericarp tissues of litchi (Litchi chinensis Sonn.) fruit in relation to their antioxidant activities. Carbohydr Res 2006; 341: 634-638.

30. CLSI: Clinical and Laboratory Standards Institute. Performance Standards for Antimicrobial Disk Susceptibility Tests, 10th ed. Approved Standard. PA: Document M02-A10; 2009.

31. Andrews JM: Determination of minimum inhibitory concentration. J Antimicob Chemother 2001; 48: 5-16.

32. NCCLS: National Committee for Clinical Laboratory Standards, Performance Standards for Antimicrobial Susceptibility testing: Twelfth Informational Supplement. Pennsylavania: NCCLS document M100-S12; 2002.

33. Thongson C, Davidson PM, Mahakarrachanakul W, Weiss J: Antimicrobial activity ofultrasound-associated solvent extracted species. Lett Appl Microbiol 2004; 39: 401-406.

34. Cook NC, Samman S: Flavonoids-chemistry, metabolism, cardioprotective effects, and dietary sources. Journal of Nutritional Biochemistry 1996; 7: 66-76.

35. Zarena AS, Sankar KU: A study of antioxidant properties from Garcinia mangostana L. pericarp extract. Acta Sci Pol Technol Aliment 2009; 8: 23-34 PubMed.

36. Tan ES, Aminah A, Khalid HM, Maskat MY, Ghani MA: Antioxidant properties of three banana cultivars (Musa acuminata Berangan', 'Mas' and 'Raja') extracts, Sains Malays 2012; 41: 319-324.

37. Galvez CJ, Martin-Cordero P, Houghton AM: Antioxidantactivity of methanol extracts obtained from Plantago species. J Agric Food Chem 2005; 53: 1927-1933. 
38. Naczk M, Shahidi F: Phenolics in cereals, fruits and vegetables:occurrence, extraction and analysis, $J$ Pharm Biomed Anal 2006. 41: 1523-1542.

39. Kang SN, Goo YM, Yang MR, Ibrahim RIH, Cho JH, Kim IS et al.: Antioxidant and Antimicrobial Activities of Ethanol Extract from the Stem and Leaf of Impatiens balsamina L. (Balsaminaceae) at Different Harvest Times. Molecules 2013; 18: 6356-6365.

40. Bajpai M, Pande A, Tewari SK, Prakash D: Phenolic contents and antioxidant activity of some foodband medicinal plants. Int J Food Sci Nutr 2005; 56(4): 287-291.

41. Kessler M, Ubeaud G, Jung L: Anti- and prooxidant activity of rutin and quercetin derivatives. J Pharm Pharmacol 2003; 55:131-142.

42. Da Silva MCA, Paiva SR. Antioxidant activity and flavonoid content of Clusia fluminensis Planch. \& Triana. Anais da Academia Brasileira de Ciências 2012; 84(3): 609-616.

43. Fasarat M, Khavari-Nejad RA, Nabavi B, Namjooyan F: Antioxidant Activity, Total Phenolics and Flavonoid Contents of some Edible GreenSeaweeds from Northern Coasts of the Persian Gulf. Iran J Pharm Res 2014; 13(1): 163-170.

44. Rojas JJ, Ochoa VJ, Ocampo SA, Mũnoz JF: Screen- ing for antimicrobial activity of ten medicinal plants used in Colombian folkloric medicine: a possible alternative in the treatment of non-nosocomial infections. BMC Comp Alt Med 2006; 6, 2.

45. Das K, Tiwari RKS, Shrivastava DK. Techniques for evaluation of medicinal plant products as antimicrobial agent: current methods and future trends. J Med Plant Res 2010; 4: 104-111 PubMed.

46. Yam TS, Shah S, Hamilton-Miller JM: Microbiological activity of whole and fractionated crude extracts of tea (Camellia sinensis), and of tea components. FEMS Microbiol Lett 1997; 152: 169-174.

47. Nostro A, Germano MP, D’angelo V, Marino A, Cannatelli MA: Extraction methods and bioautography for evaluation of medicinal plant antimicrobial activity. Lett Appl Microbiol 2000; 30: 379-384.

48. Duarte MC, Figueria GM, Sartoratto A. Rehder VL, Delarmelina C: Anti-Candidal activity of Brazilian medicinal plants. J Ethnopharmacol 2005; 97: 305-311.

49. Tortora JG, Funke RB, Case LC: Microbiology: An introduction. 7thEdition, Pearson Education, Incorporation Publishing 2002.

50. Gatsing D, Nkeugoauapi CFN, Nkah BFN, Kuiate JR, Tchouanguep FM:Int J Pharmacol 2010; 6: 173-182. 